\title{
O diário póstumo de Hervé Guibert: espaço de escritura, decantação da gramática autobiografemática e ato final de um projeto autoficcional
}

Willian Vieira ${ }^{1}$

\section{QUANDO LE MAUSOLÉE DES AMANTS² ${ }^{2}$ ÚLTIMA OBRA DE HERVÉ GUIBERT, VEIO À LUZ EM 2001, DEZ ANOS APÓS} SUA MORTE, CRÍTICOS, JORNALISTAS E LEITORES SE DEBRUÇARAM COM VORACIDADE SOBRE O LIVRO. Afinal, ele se vendia como um diário: “Journal 1976-1991” é o paratexto na capa da versão de bolso - logo acima de uma foto do autor nu coberto por um véu. Guibert traduziu sua trajetória de escritor acometido pela AIDS que definha em praça pública em uma série de livros, dos quais À l’ami que ne m’as pas sauvé la vie foi o mais celebrado, polêmico, vendido - ali ele anunciou que tinha a doença, então sentença de morte, utilizando sua própria identidade (a homonímia o alçou à condição de autor de autoficção) para tal. Então todos foram em busca das “provas” de que À l'ami era, de fato, o registro real, não ficcional, de uma vida.

Mencionado em quase tudo o que escreveu o autor-narrador-protagonista ${ }^{3}$ e disse seu autor real, como tal, o diário de Guibert à época de sua publicação já era uma instituição literária, algo da ordem do mitológico. A cena do escritor para cima e para baixo com um volume que ele definia como "le journal" e no qual anotava o que via, sentia e vivia - e de onde brotavam os germes de livros futuros - está presente na maioria de seus livros ${ }^{4}$ e em muitas entrevistas. Mas M.A., como tudo escrito por Guibert, é obra difícil de classificar: seria um diário escrito para si? Um depositário de ideias e escritas que traduziriam um processo de criação paralelo ao romance? Ou um romance stricto sensu, pensado enquanto tal para mimetizar a escrita de si que existe num diário de escritor, e logo para ser publicado a posteriori? Ou seria tudo isso de uma vez, cabendo ao leitor decidir seu estatuto?

Aqui não se pretende cotejá-lo com toda a obra do autor em busca de relações de referência; isso foi feito em outros trabalhos. Trata-se, sim, de analisar como o livro se relaciona com o discurso metacrítico do autornarrador-protagonista sobre seus processos de escrita e sua relação com a escritura e a vida real; com a "escrita

\footnotetext{
${ }^{1}$ Doutor em estudos literários pela USP. Contato: vieira.will@gmail.com.

${ }^{2}$ A partir daqui, o livro será referido como M.A. A tradução dos trechos é do autor deste artigo. O livro nunca foi traduzido ou publicado no Brasil.

3 "Esse narrador homônimo ao autor que conta a mesma vida (recontada também pelo autor de carne osso de forma performativa epitextual) é o protagonista da história, centrando na autorreferência e na meta-narrativa seu foco de narrador em primeira pessoa”. Ver: VIEIRA, W. "Em literatura pode-se dizer tudo'. Poética do eu, ontologia do não-limite e política da autoficção em Hervé Guibert, Christine Angot e Ricardo Lísias”. 2019. Tese, p. 26.

${ }^{4}$ A relação com o diário é intrínseca aos processos de criação de Guibert: em Les aventures singulières e Voyage avec deux enfants, por exemplo, livros compostos por nouvelles, historietas cotidianas centradas no autor que escreve e que anda com cadernos e com o diário para onde vai, anotando o que pensa e vive, essa relação problemática entre notação diarística e a escrita missivística sem resposta é trabalhada. Em L'homme au chapeau rouge, ele escreve: "Aqui se encontravam cinquenta páginas do meu manuscrito que se perderam. Era o relato de minha viagem à África” (p. 165). O narrador conta que despachou o manuscrito, mas teve a presença de espírito de reaver seu diário (de 15 anos) antes de a mala sumir na esteira de bagagens. O maior temor desse autor-narrador-personagem é que “o diário" se perca.
} 
imediata"; com sua relação problemática com o romance como gênero; com sua defesa de certo tipo de literatura calcada na indefinição estatutária; e, sobretudo, com sua poética do inacabado. Nos processos de criação guibertianos, sustento, existe a perspectiva estética de uma recepção engajada. Afinal, com M.A., Guibert encerra de forma brilhante seu projeto autoficcional.

\section{A escrita guibertiana: o diário como fonte de escrita}

Guibert escreveu outros dezoito livros (além de escritos que acompanham coletâneas de fotografias, cinema, dentre outros). Em boa parte deles, a escrita diarística se impunha, tanto como tema - a vida que se liga indissociavelmente à escrita, a seus processos, sobretudo quando há menções metatextuais ao próprio diário, à sua existência e sua função no processo de escrita - quanto na forma: entradas com data e/ou local, seguidas de notas no estilo presente sobre fatos cotidianos recentes. Em suma, quase sempre é perceptível a presença do diário na escrita guibertiana. Ainda que isso não garanta certeza de origem do real (pode ser uma formalização estética, mimetização de um discurso de verdade e intimidade), fato é que ela funciona.

O primeiro choque de quem lê $M . A$. é perceber que não há "entradas" como nas outras apropriações do diário na obra do escritor. Não há datas, referências a lugares ou tempo definido, exceto algumas menções a dias de semana ou mês, noite ou dia, etc. A única cronologia possível a ser seguida é a menção esporádica à idade do narrador (como à p. 243 e à p. 429) e as fartas menções aos nomes das obras do próprio Guibert durante seu processo de escrita e publicação. Por quê? Talvez dessa vez, quando finalmente vai publicar o material bruto (editado ou não, veremos) de seu obsessivo processo de notação da vida e da escrita, ele já não precise desse suporte. Não há mais necessidade de aludir a uma suposta pureza originária da notação diarística. A forma se impõe de tal maneira que o autor busca inclusive o contrário: despojar o que se lê de anteparos entre a menção direta às ideias em germe e o aprisionamento temporal do diário ${ }^{5}$. Meu ponto é justamente esse: antes de ser um diário sobre os amores de Guibert, como pretende o título póstumo ${ }^{6}$, esse é um romance (no sentido guibertiano do termo: uma narrativa autoficcional) sobre o processo de escrita autoficcional guibertiano. Ele só é um romance sobre o amor se entendermos por amor a relação de Guibert com sua escritura.

Todos os elementos que foram ganhando espaço de forma paulatina em suas obras estão aqui, condensados de maneira bruta. Há, por exemplo: a) o exemplo mais claro de seu projeto autoficcional, esta escrita de si como desnudamento anunciado, postura autobiográfica de enfrentamento do real que Blanckeman (2008) define como "impostura romanesca"; b) a escrita fotográfica, que transcreve imediatamente a experiência vivida como se de fato se tratasse de uma entrada no diário $^{8}$ - desde L’image fantôme, Guibert estabeleceu um diálogo entre a fotografia (que perdia espaço em sua vida) e a escrita fotográfica, imediata, que ganharia espaço em sua escritura.

\footnotetext{
${ }^{5}$ Os originais do diário não existem - nem mesmo no Fonds Hervé Guibert no IMEC, França.

${ }^{6}$ Talvez retirado da passagem seguinte: "Je rêve d'un mausolée rond, en forme de coupole, traversé de part en part par les gisants des amants qui y sont enterrés” (p. 197).

${ }^{7}$ Analisando de forma ensaística toda a obra guibertiana, Blanckeman separa em sua noção de "posturas autobiográficas" a "frontalidade" e a "captação". A primeira, a postura frontal da narrativa, "consiste em olhar de frente os períodos de existência, reduzindo ao máximo a distância que separa a experiência de sua narração, uma urgência de outra vida mais que memórias do além-túmulo”. BLANCKEMAN, B. Les récits indécidables: Jean Echenoz, Hervé Guibert, Pascal Quignard. Villeneuve d'Ascq: Presses universitaires du Septentrion, 2008, p. 91).

${ }^{8}$ Ver: Vieira, pp. 65-71, op. cit.
} 
A fixação pela apreensão do momento (escritura fotográfica) faz do diário o único material de escrita possível; c) a relação frutífera e intercambiante do romance com outros espaços de escritura, da caderneta à carta ao diário; d) a metanarração, o comentário metacrítico do autor-narrador-personagem e o questionamento (transformado em jogo, provocação, leurre, sobre o estatuto do real e do imaginário); e) a definição de um tipo de escrita que reflete o processo de escritura, de notação, como sendo sua literatura mais própria; f) o topos da morte como espetáculo g) e a cristalização do topos do martírio do escritor. Tudo o que um leitor assíduo de Guibert já conhece de seus romances se encontra nas páginas do diário.

O que não é uma surpresa: o diário, segundo afirmações do narrador guibertiano nos romances publicados, e do próprio autor em entrevistas, era a "espinha dorsal" de um projeto de escrita, o espaço de escritura privilegiado de onde saíram seus livros. Qual seria a relação do diário com seus romances, perguntou o jornalista François Jonquet. "Uma relação determinante: muitos dos meus livros saíram dele. É muito comum que um escrito nasça porque há, no interior do diário, um tema ou um personagem que, tornando-se muito insistente, desequilibrava ou quebrava esse equilíbrio cotidiano", respondeu Guibert, completando:

Mes parents, por exemplo, saiu em grande parte do diário. Fou de Vincent, igualmente. O diário permite lançar pontes entre universos diferentes: passar das minhas tias aos relatos eróticos. Meus livros são apêndices e o diário, a coluna vertebral, a coisa essencial ${ }^{9}$.

Se Mes Parents já continha partes cuja formatação textual e estilo de escrita sugeriam ser oriundas de um diário (e o próprio narrador afirmasse se tratar de uma parte de seu diário) ${ }^{10}$, em Fou de Vincent toda a estrutura do livro é diarística, mas retrospectiva. E esse "personagem que, ao se tornar insistente demais, desequilibra ou quebra esse equilíbrio" do diário e que dele saía para se transformar em tema de romance, era Vincent, seu amante. É o que o leitor depreende da conjunção entre a leitura do romance e as entrevistas de Guibert.

Em Fou de Vincent, ele perverte o registro do diário íntimo, não só com a cronologia inversa, mas com a implementação de uma lógica: no caso, narrativa (da morte como um destino trágico), distinta da do registro diário imediato típico, como define Béatrice Didier ${ }^{11}$. Para Guibert, "o pseudo-diário íntimo se transforma num procedimento romanesco" ${ }^{12}$. E mais que isso: o diário, lugar de escrita, de notação do real imediato e das ideias de escrita que se ligam à vida, se transforma no escoadouro de biografemas do escritor enquanto escritor.

É o que chamo aqui de autobiografema ${ }^{13}$, expandindo o conceito original barthesiano: o "autobiografema" é essa espécie de vocábulo autobiográfico, de building block narrativo, que pode se encaixar em narrativas diversas

\footnotetext{
9 "Je disparaitrai et je n'aurais rien caché", Globe, fev. 1992, entrevista a François Jonquet.

${ }^{10}$ É curioso descobrir que Mes parents não era a ideia inicial de Guibert. O escritor procurara o editor Hector Banciotti, da Gallimard, para publicar seu diário na íntegra, antes recusado pelas Éditions de Minuit. Foi o editor que sugeriu o corte no diário, extraindo somente as partes sobre os pais. Guibert diria, mais tarde, que seu diário (que seria publicado postumamente) teria ficado "pior" após a publicação de Mes parents.

${ }^{11}$ DIDIER, B. Le journal intime. Paris: PUF, 1976, p. 140.

${ }^{12}$ GENON, Arnaud. Roman, journal, autofiction: Hervé Guibert en ses genres. Paris: Mon Petit Editeur, 2014, p. 70.

${ }^{13}$ Para o debate sobre o conceito de biografema, de onde surge o de "autobiografema", ver: Vieira, W., pp. 44-46, op. cit. Na tese, explano o conceito original de Barthes desde o prefácio de Sade, Fourier, Loyola (1971, p. 706), passando pela definição de Pino e Amaro (2018, p. 170) e Pino (2016, p. 19). Ver: PINO, C. "De um corpo para outro. Roland Barthes e a
} 
sobre esse eu que se projeta. Esse não é um naco de vida que voa longe sem destino: é um átomo que vibra na obra do autor vivo, no presente da escritura e que permite, quando revisitado, quando cotejado a outros, a criação da própria obra.

Como define Vigna ${ }^{14}$ ao ler Millás, por meio do autobiografema, nos encontramos "frente a um eu cuja identidade aparece esboçada, e estetizada, a partir de cenas vividas", essas "ordenam a lembrança e, logo, a vida"15. Desta forma, estabelece-se "um contínuo cruzamento entre uma ficção propriamente dita e outra, que se apoia na realidade biográfica" (idem), ao ponto em que sua evocação contínua, "a partir das vivências experimentadas", constrói todo um universo autoficcional. Vigna pensa os autobiografemas como os quatros de uma grande casa, que o autor percorre em busca de um sentido para a vida que narra pela escrita.

O nascimento, a casa de infância, o livro sendo escrito, a profissão de escritor, a promessa que deve ser cumprida - no caso, escrever o romance que se anuncia - são os autobiografemas que Vigna encontra em Millás. Em Guibert, teremos ainda o romance inacabado, a relação com a escrita fotográfica imediata e a perda do momento, a pulsão de morte espetacular, etc. Cada vez que é invocado, diz, o autobiografema funciona como o punctum barthesiano, capturando a atenção do leitor e devolvendo-o ao contínuo da obra-vida.

Do ponto de vista criativo, os autobiografemas são como os quartos da imensa mansão do "espaço autobiográfico" - como pensando por Lejeune e atualizado por Prado Biezma e Nora Catelli ${ }^{16}$ - do autor que não mais se distingue do narrador-protagonista. É com eles que o autor-narrador-protagonista se constrói como entidade enunciativa íntima e indissociável para o leitor, que ganha vida na escrita. Do ponto de vista do leitor, esses "signos de identidade", essas "marcas" que deixam antever "a presença do eu autor, causa substancial da escritura" (1994, p. 2020) - ou seja, esses "signos de realidade" que ligam as obras ditas ficcionais, a escrita imaginativa, e os elementos referenciais, como a carta e o diário - constituem esse "espaço retórico do eu", como pensa Catelli Sem esses autobiografemas, qualquer autorreferência intratextual se torna inacessível e sem o conhecimento apriorístico dos quais uma relação profunda de leitura, na lógica da autoficção, torna-se incompleta.

Juntos, eles compõem uma gramática autobiografemática, esse vocabulário de elementos narrativos intercambiáveis que permitem recontar a vida do escritor que se escreve e vive para escrever, o que permite ao autor-narrador-protagonista colocar sua narrativa em relação à obra como um todo e situar o leitor em relação a essa obra maior, dando um significado uma potência sincrônica que ultrapassa o texto em questão ${ }^{17}$. É ela que

biografemática”. Revista Criação \& Crítica, (17), 2016 e PINO, C. A.; AMARO, L. "Del biografema a la comunidad: dos casos recientes en la literatura latino-americana”. Alea [online]. 2018, vol.20, n.2.

${ }^{14}$ VignA, G.A. "El peso de mis autobiografemas. Construcción de la identidad en el mundo de juan josé millás”. Tonos Digital, 2018, p. 2.

${ }^{15}$ Vigna absorve o conceito de autobiografema de Sylvia Molloy (1996), que propõe o termo para identificar as vivências biográficas pelas quais quem se narra ordena sua memória, seu entendimento da vida passada e presente e logo a escrita dessa vida.

${ }^{16}$ LejEUne, P. Le pacte autobiographique. Paris: Éditions du Seuil, 1975. PRADO BIEZMA, J. et alii. Autobiografia y modernidad literaria. Cuenca: Ediciones de la Universidad de Castilla-La Mancha, 1994. CATELLI, N. En la era de la intimidad: seguido de El espacio autobiográfico. Rosario: Beatriz Viterbo, 2007.

${ }^{17}$ É algo próximo ao que Boulé (2011) define como "filões narrativos". E algo similar ao que Gasparini define como "enciclopédia pessoal" (2008, pos. 669) do escritor e que o leitor acessa, como vimos acima, de forma repetida, iterativa e estereotipada. Ver: Boule, Jean-Pierre. Hervé Guibert : L'entreprise du moi. Paris: L'Harmattan, 2001 e GASPARINI, Philippe. Est-il jeu ? Paris: Seuil, 2004. 
permite o caráter de iteração que a autoficção nos moldes guibertianos oferece: a cada menção a autobiografema, uma obra se liga a outras num todo "intratextual", reafirmando o pacto autoficcional de leitura. O autornarrador-protagonista, entidade identitária e enunciativa, oferece ao leitor um universo de autobiografemas, átomos biográficos facilmente conjugáveis entre si (tanto na escrita como na leitura) e que permitem ao leitor, via iteração e intratextualidade, um acesso privilegiado ao mundo do texto.

Em Guibert, esses autobiografemas giram quase sempre em torno da própria escrita, da escritura contínua de si em seus livros. O martírio do escritor, o romance fracassado, a escrita fotográfica em oposição ao romance realista - eles fazem parte da obra guibertiana, e no diário estão concentrados, como se ele fosse sua fonte. Se os autobiografemas, sobretudo os ligados à escrita, alimentam a própria escrita dos romances, sua presença no diário será cabal. O diário traz a decantação absoluta da gramática autobiografemática.

Tanto que Guibert, em entrevistas, reafirmou sempre a existência do diário como origem do romance. Claro, sua fala é também performática e literária, texto pronunciado pelo mesmo "je" que se projeta no diário e no romance. Esse espaço de escritura (o diário) é como um berçário de ideias e obsessões. Mas o diário é um lugar de produção de escritura contínua, que o autor interrompe sempre que surge uma monotonia promissora (e incômoda). Como diz Genon, M.A. parte do diário, espaço de escritura em si, e ganha contornos "reguladores de uma prática obsessiva de escritura" ${ }^{\prime 1}$. Guibert, desde jovem, utilizava suas anotações (tomadas em diversas cadernetas) para alimentar um diário datilografado, que serviria de base para vários de seus livros ${ }^{19}$. A escritura imediata, tomada à caderneta, era repassada ao diário, espécie de manuscrito central ou de espaço de escritura em movimento.

Se boa parte dos livros de Guibert têm trechos presentes em M.A., nada se encontra ali, por exemplo, a respeito de Fou de Vincent. Podemos pensar que algo se perdeu. Guibert não teve um único diário, nem chamava de journal apenas um volume. O diário era seu espaço de escrita contínua, espaço relacional entre sua vida e sua consciência, só revelado quando vertido no papel. Então o livro não se trata apenas de um simples diário, em que o autor anota o que pensa todo dia: o diário é a espinha vertebral de toda a escrita autoficcional, quase sempre imbuída da formalização diarística e de sua potência criadora. O diário é um livro autoficcional como qualquer outro de Guibert.

\section{A recepção do livro-diário}

Reler no diário os trechos reconhecíveis de $A$ l'ami e outros livros traz uma sensação de refiguração peculiar, espécie de forma mais potente da iteração biografemática, visto que o relato póstumo detém um poder de silenciamento futuro (essa será a última narrativa possível) e de reconfiguração dos relatos passados - seu caráter de ressignificação retrospectiva da empreitada literária de Guibert. Por exemplo, após uma das mais belas passagens da primeira parte de À l'ami, em que o narrador visita Muzil no hospital (no diário, o nome é Michel, já que se trata de Michel Foucault), beija-o, chega em casa e lava a boca, ele escreve: "Suprimir as passagens precedentes? Ontem Michel estava com uma cara bem melhor" (p. 332).

\footnotetext{
${ }^{18}$ Op. cit., (2014, p. 53).

${ }^{19}$ A irmã do autor, responsável pela publicação póstuma de M.A., disse em entrevista: "Hervé escrevia em cadernos, na verdade. Daí ele reescrevia à máquina, modificando algumas coisas, excluindo outras". VIVIANT, A. "Le Revenant”, Les Inrockuptibles, 27 nov. 2001.
} 
A ideia de que parte do livro pudesse ter deixado de existir pode ser chocante para o leitor. Eis um exemplo de como a publicação de M.A. oferece ao leitor um suprassumo decantado da escrita guibertiana. Como sua composição utilizou um expediente de estratégias de persuasão que funcionam, em relação à leitura, como um guia para a escritura de Guibert - pois o livro amarra ontológica e pragmaticamente, de forma retrospectiva, toda sua obra.

O primeiro ponto a ser analisado deve ser: como um livro que só foi publicado dez anos após a morte do autor (enquanto seus outros livros póstumos foram publicados nos anos seguintes), e que se coloca editorialmente como diário, é recebido pelo horizonte de expectativas do leitor de Guibert? Parece óbvio pensar que o objetivo deste leitor-detetive, voyeur interessado na prática de escritura, seja encontrar os segredos dessa prática ainda não revelados, as chaves de leitura, os cruzamentos possíveis. O diário seria o alimento final para o leitor que busca se saciar pelo resto decantado, maturado e esquecido do corpo escrito do autor-narradorprotagonista. É o que vende, em suma, o paratexto principal da obra:

O personagem principal tem entre vinte e dois e trinta e cinco anos. Ele é jornalista, aspira à escritura, não para nunca de trabalhar num romance fracassado com um personagem na terceira pessoa. O romance se chama Le récit de la mesquinerie, mas não vê a luz do dia. E ele muda: vira uma história de amor. Percebe-se, na trama desse livro, vários livros em um, e também vários livros recusados: um que se chamaria Roman posthume, outro que se chamaria Autobus et métro, uma continuação de Aventures singulières, um Journal de travail ("Diário de trabalho"), mais é o Récit d'amour que domina: construído como um mausoléu para o corpo dos amantes. Sobressai, acima de tudo, a recusa de costurar um romance para, em vez disso, entregar a matéria bruta, a continuidade viva da vida, sonhos, encontros, aventuras.... H.G.

Assinado com as iniciais de Guibert, a quarta capa levanta questões. Até que ponto o livro foi editado pelo autor em vida, já que ele assina, dez anos após sua morte, o paratexto? Se é um diário, por que falar em "personagem"? Se há vários livros em um, o diário confirma o que dizia Guibert em seus epitextos, sobre ser a espinha-dorsal de sua escritura? Qual relação com esse Journal de travail que nunca saiu - seria ele, em parte, o próprio volume de M.A.? E mais: essa "recusa de finalizar um romance para entregar dele a matéria bruta, a continuidade viva da vida" - até que ponto ela é a essência mesma da escritura guibertiana? Muitas respostas jazem no livro. Por isso, pretendo analisar o diário como livro, escritura, deixar a narrativa do livro contar sua história. Assim, veremos como o leitor encontrará respostas a novas perguntas, que não deixam de o aproximar ainda mais do autor-narrador-protagonista.

Antes, vale atentar para a recepção do livro na imprensa. Os críticos viram em M.A. um grande livro - em nada diferente dos outros de Guibert. Ninguém pretendeu ver no diário só um diário, mas uma obra literária do começo ao fim. M.A. "foi praticamente todo talhado e retrabalhado pelo autor antes de sua morte" ${ }^{20}$. Como ele sabe? Para a crítica do $L^{\prime}$ express ${ }^{21}$, o primeiro elemento a se levar em conta é justamente o silêncio que Guibert exigira, via testamento, antes da publicação do diário: Guibert sabia que uma pausa entre o escândalo da AIDS e

\footnotetext{
${ }^{20}$ LANÇON, Philippe. “Hervé Guibert est dans le journal”. Libération, 27 de dezembro de 2001.

${ }^{21}$ RABAUDY, Martine de. "Le trompe-la-mort”. L'express, 6 de dezembro de 2001. Ela diz ainda: "Ao destiná-lo à publicação, Guibert cuidou de fazer ouvir a mesma música que em suas partituras romanescas”
} 
sua obra decantada se fazia necessária. M.A. traria, assim, "a matéria primeira dos romances de Guibert" (idem), mas não seria seu rascunho. A mesma música, a mesma voz, o mesmo tipo de literatura (autoficcional). E Para a crítica do Le Monde ${ }^{22}$ (jornal que deu um grande espaço ao livro, inclusive na capa), "descobrimos a gênese de vários livros", "mas pode-se começar nesse livro e depois ir aos outros romances" (idem). Não se trata de caçar as chaves de leitura da obra anterior, diz a crítica. O livro funciona por si só.

Mesmo com todo grau de retrabalho narrativo sobre os registros (que só podemos confirmar pela lógica de seleção $^{23}$ e cronologia), resta um caráter de hibridez: mesmo não havendo como comparar as entradas do diário com a suposta realidade, e tampouco as entradas do livro com o que seria o verdadeiro diário, podemos comparar as entradas do diário com outras obras publicadas pelo autor - nas quais a repetição intertextual é flagrante -, o que constrói, pelo exercício de comparação intertextual, uma dimensão de existência fora da obra (pela noção de colagem ou autorreferência).

É esta a estratégia de persuasão que faz com que, ao ser lido, o livro se apresente como híbrido entre verdade e ficção - sobretudo quando, nos próprios fragmentos denuncia-se como empreitada mista. Para Braud ${ }^{24}$, "a autobiografia na qual o diarista não elabora seu discurso íntimo" é por ele composta "para representá-la diante do outro como uma formatação do real e por demandar do outro uma apreciação como tal. Mas essa "mise en forme du réel", por mais que admita uma ideia de "composição", dirige-se a um suposto real - e é esse o coração da estratégia textual guibertiana, da qual M.A. surge como corolário póstumo.

Mas a ambiguidade entre registro autobiográfico imediato e ficcionalização a posteriori não pode ser anulada pela mise en intrigue. Sobretudo quando a recepção da obra é marcada pelo metadiscurso do autornarrador-personagem dentro do livro (e sobre o livro, como veremos, já que se trata de um livro sobre a escrita de livros), e por todo o arcabouço epitextual construído pela recepção da trajetória de Guibert, em parte arquitetada por ele mesmo.

A transparência e a materialidade da escrita ${ }^{25}$ são aqui igualmente fartos como no restante da obra autoficcional de Guibert e corroboram esse efeito de verdade. "Ontem de noite, num ônibus (eu me lembro dessas três histórias na sequência, hoje de manhã num café, esperando a abertura do museu), me ocorreu que...” (M.A., p. 217). Ele fala o tempo todo em "este caderno", "este diário", pontuando sua relação com a história, o registro da história, a transposição do registro de um modo a outro de escrita. "Eu me coloco, ao começar a digitar este diário, como pesquisador de mim mesmo" (Idem, p. 321). Os mesmos elementos que garantiam uma recepção dúbia, marcada por um efeito de verdade, de intimidade, ganham aqui o aporte nada desprezível do gênero diarístico publicável.

Diz o narrador: "a extraordinária sorte da escritura: que acreditemos quase sempre no que lemos no momento em que lemos, que a leitura porte em si esse fenômeno de crença" (idem, p. 379). Crença que não se limita à dimensão referencial da entrada de diário, mas que ganha com ela um surplus. Isso sem mencionar um elemento extra de sucesso na publicação de M.A.: se o documento concreto do manuscrito do diário não está

\footnotetext{
${ }^{22}$ SAVIGNEAU, Josyane. "Pour retrouver Hervé Guibert". Le monde. 23 de novembro de 2001.

${ }^{23}$ A seleção se torna patente, por exemplo, quando lemos que Guibert retirou Fou de Vincent integralmente do diário, como vimos, e não encontramos qualquer trecho do romance em M.A..

${ }^{24}$ BRAUD, M. La Forme des jours: pour une poétique du journal personnel. Paris: Seuil, 2006, p. 256.

${ }^{25}$ Tais conceitos são destrinchados na referida tese. VIEIRA, W., pp. 36-41, op. cit.
} 
disponível, não apenas nunca se conhecerá seu caráter de edição como a dúvida tomará conta de cada um dos fragmentos do livro, permitindo qualquer análise. Assim, a suspensão do estatuto, que já garantia o efeito estético único dessa literatura, contamina retrospectivamente a análise crítica com a mesma suspensão. E a recepção acaba seguindo o mesmo caminho da maioria das outras obras de Guibert: ela é ambígua, equilibrandose entre o discurso de verdade e a ficção, entre a intimidade do diário e o distanciamento estético imposto pela formatação do livro e pela figura (pouco confiável em termos de contrato de leitura) de Guibert.

\section{Do diário como romance da vida à dialética da escritura diarística}

O primeiro espaço de escritura que Guibert parece ter construído em sua vida de escritor é reflexo de sua relação pessoal, íntima, amorosa, com T., seu mais frequente "personagem", como ele diz, além de si próprio. É o que testemunha o primeiro fragmento de M.A., separado (na edição publicada em volume) do resto da obra por uma folha em branco (sem mencionar o uso do verbo no imperfeito, o que lhe confere um ar epigráfico que banha o restante do livro, prospectivamente, com o signo de sua importância).

(Eu escrevia cartas a T., sob a dor as palavras saíam, mas eu não as enviava, eu colocava o envelope carimbado com seu nome em uma caixa de madeira branca, e ele vinha lê-las, elas estavam à sua disposição (...) As cartas pararam, o caderno tomou seu lugar, era então onde ele podia vir ler, a qualquer momento, na minha ausência. Eu lhe deixava as minhas chaves para que ele ficasse à vontade para consultá-lo. Agora eu abro a caixa em público, eu abro o caderno e o deixo aberto, exposto: eu posso facilmente me imaginar morto (Idem, p. 9 , grifos meus).

Sua literatura nasceu dessas cartas a T., como diria Guibert em entrevistas ${ }^{26}$. "Sem ele, eu não escrevo, eis a realidade, ele escreve tanto quanto eu ao enfiar a língua em minha boca” (Idem, p. 178), diz o narrador. É o "drama" imposto pela presença ou ausência de T. que o faz escrever. O primeiro espaço de escritura - aberto, exposto durante o percurso, antes de qualquer noção de obra acabada ou gênero definido - era a caixa de cartas e logo o caderno (que viria a ser o diário datilografado) dedicado a $\mathrm{T}^{27}$. A caixa repleta de cartas que não esperavam respostas (a carta era uma forma de narrar sua experiência, gênero que lhe permitia dizer-se ao outro, uma forma de diário íntimo aberto ao outro) é um espaço de escritura que logo se transformará no caderno e, mais tarde, na decantação de um processo que culminará no diário.

Sem data nos fragmentos, é difícil saber quando Guibert escreveu esse primeiro trecho, que parece introduzir o diário como obra. Assim, como saber se o autor-narrador abre a caixa (no sentido metafórico) ao público quando começa a publicar suas obras ou quando imagina o diário pronto para publicação - no sentido da decisão, como veremos? O que leva a pensar, do ponto de vista do leitor: qual o grau de edição, de retrabalho, no diário?

Os primeiros fragmentos sugerem um germe de metonímia que trairia uma reescrita posterior. No primeiro deles: "Canto de janela: lugar vazio, onde eu vou colocar esse manequim de criança se eu o comprar" (p. 11); e, no terceiro: "Do outro lado da janela me sinto observado e fujo". "Decido me ver fazê-lo eu mesmo sem jamais

\footnotetext{
26 "Je disparaitrai et je n'aurais rien caché", Globe, fev. de 1992, entrevista a François Jonquet.

${ }^{27} \mathrm{O}$ narrador reconhece que o fato de $\mathrm{T}$. ter acesso permanente ao diário o mantém num estado de "radiografia permanente", como se ele se visse obrigado a dizer tudo o tempo todo, o que faz dele "um homem nu" (p. 45).
} 
virar o olhar para o observador" (p. 12). Ele abre um envelope, tira uma folha branca finge ler. "Que significado tal gesto pode ter para o observador?" (idem). É um gesto "premeditado", com o único objetivo de despistar quem o observa. Quem é esse observador senão o leitor, que acaba de adentrar o espaço de escritura que antes pertencia apenas a T.? O gesto de pretender acessar, frente ao observador, um documento real, íntimo, como a carta tem o que de premeditado? Seria esse fragmento (datado de 1976, se levarmos em conta a ideia de que o diário segue a cronologia estrita) dotado de um caráter premonitório, mais uma vez, sobre o projeto literário de Guibert ou seria um clin d'oeil guibertiano sobre o estatuto em suspensão da obra que o leitor tem em mãos?

Genon $^{28}$ afirma que M.A. é uma obra literária à parte, "e tudo o que isso implica de construção, composição, reagenciamento, correções...", e não um documento não literário, “ao qual Guibert teria dado uma importância secundária" ${ }^{29}$. Do ponto de vista da criação, não resta dúvida de que o livro foi preparado para publicação (Guibert falará, no próprio livro, sobre sua possível publicação) - e o próprio fragmento que serve de introdução deixa claro o caráter editado do diário. O que a estratégia editorial chama de "diário" deve ser interpretado da forma como Guibert se relacionava com ele: não como diário íntimo, mas como espaço de trabalho literário e de referência do vivido - basicamente, como um espaço de escritura.

A priori, faz sentido pensar que se trata de um livro sobre o amor. Pouco a pouco, porém, o trabalho de escritura ganhará espaço como tema da própria escritura do diário - que se mostra, como bem definiu Lejeune como "laboratório de suas autoficções"30. A sensação de que acompanhamos o diário de trabalho do escritor logo ganha corpo. O diário é o espaço não só de transcrição do cotidiano do narrador, seu espaço de criação, mas também essa "longa faixa contínua, otidiana, que se relaciona com a relação que se tem com ele (o diário)" (p. 188). É onde ideias viram projetos, onde eles são retomados ou abandonados, é um espaço de diálogo consigo, com o texto e com o mundo. Vide o trecho a seguir, provavelmente relacionado a $\grave{A}$ l'ami: "Releio uma parte bastante antiga do diário para ver se devo incluir excertos no romance; e as acho terríveis" (p. 452). O enxerto permite a Guibert alimentar um projeto com uma verdade (a seu ver) do passado, criando uma sincronia que vai além da diacronia autoficcional.

Do ponto de vista da estratégia de sedução do leitor, mostrar da forma mais escancarada possível seu "local" de trabalho, seu espaço de escritura, é o grande tema do livro, sua novidade. Antes, em cada livro, Guibert trouxe um pouco de seus processos, sua forma de conceber a vida e a literatura como indissociáveis. Aqui, nesse espaço de escritura, o leitor consegue traçar uma genealogia do romance. Vide o caso de Les gangsters nas três citações abaixo:

Profundamente chocado, como se diz, pelo que acaba de acontecer com minhas tias-avós (o lance dos gângsteres).

\footnotetext{
${ }^{28}$ GENON, A. Op. cit, p. 88.

${ }^{29}$ Genon assim define M.A.: "Desde o início se o lê como um texto fragmentário, um patchwork de anotações, de pensamentos, de tentativas de romance, de relatos de sonhos que se voltam constantemente a quem está na origem do livro: T.” Idem.

${ }^{30}$ LEJEUnE, P. “Le journal comme 'antifiction”. Poétique, n. 149, 2007, p.6.
} 
O que é excitante, no desejo novo, imprevisto, de contar uma história (Les gangsters), é entrever uma infinidade de ramificações e, ainda que vagamente, a estrutura que os fará se desenvolver.

Sem dúvida é uma longa história, e estou bem dentro dela, eu vi seu começo... (Idem, p. 419, grifos meus).

Do acontecimento real, passando pela ideia de transformá-lo em literatura até o nascimento do título e do primeiro esboço de estrutura, está tudo aqui, entregue ao leitor. O diário é também seu espaço de metacriação, de reflexão sobre a literatura, no qual pode anotar uma frase, oriunda de uma carta a T., e perceber que a transposição denuncia um drama de escritura, que ele precisa viver para contar. A frase tem "um fundo de verdade", mas é "um pouco mentirosa", tomando "uma direção romanesca", virando um Frankenstein (p. 189).

"Falta de T. e perda da escritura : estou como se alguém me tivesse desligado, cortado meu nervo amoroso" (As anotações do diário são muitas vezes o fato de uma exageração, de uma tentação: assim, essa frase, que eu escrevi numa carta a T., e que recopio: ela tem um fundo de verdade, mas só um fundo, um fundo profundo, último, mas ela é também um pouco mentirosa: eu não estou a esse ponto abandonado pela escritura, mas sim tentado a estar, esse estado (ou sua suposição) me agrada, é um esboço romanesco, me agrada sonhar que sou uma criatura de T., Frankensteins da escritura (Idem, p. 189, grifos meus).

Por que explicar a si mesmo o papel do diário, se não fosse com vistas a esclarecer sua escritura ao leitor, ou suspender novamente o estatuto de sua escrita? ${ }^{31}$ Para o leitor, tal entrada concede mais uma chave de leitura, ao reafirmar seu desejo de vivenciar um drama que pode ser transposto, então, como verdade ao diário, do qual uma nota seguinte poderá arrancar a própria essência ou desmentir a afirmação. Tal dialética da escritura diarística pode ser pensada como o cerne da escrita guibertiana, a ponto de o embate entre verdade e ficção, tantas vezes mencionado pelo autor e tão central em toda crítica, ser a ele subjugado. É no diário que Guibert formula ideias de livros e pensa o específico de sua literatura: "Para o livro: o entrelaçamento de dois estratos de memória; a memória imediata, parcial e tateante do diário; a memória vaga e sintética do relato em trabalho” (p. 442). Entre a entrada imediata no diário (ou caderno, ou carta) de uma experiência vivida e o retrabalho da memória que sintetiza, a partir do diário, uma narrativa autoficcional, existe um entrelaçamento impossível sem esse espaço de escritura.

Essa noite, um tanto entediado, dou uma olhada nos antigos cadernos: eu gostaria de passá-los a limpo, mas ao contrário, partindo desse ponto. Quando mais me distancio no tempo passado,

\footnotetext{
${ }^{31}$ Guibert se mostra, no próprio livro, um grande leitor de diários de outros escritores, sendo o de Kafka o mais mencionado. Sabemos também que Guibert tinha uma relação com o diário de grande literariedade, a ponto de tentar publicá-lo, sem êxito, pelas Éditions de Minuit. Algo que fazia parte de seu zeitgeist, como bem lembra Braud: "1978 é o ano de publicação do primeiro volume do diário de Charles Juliet, que pode ser considerado como um dos primeiros diários, no campo literário, a ter sido publicado por seu autor como primeira obra e não após vários volumes de ficção ou de poesia diário-obra, no sentido pleno do termo" (op. cit, p. 76).
} 
mais tenho impressão de que as coisas anotadas evaporaram, se descarnaram, foram absorvidas aos poucos pelos meus livros vizinhos (idem, p. 306).

O narrador relê suas notas e imagina uma nova estrutura para contar sua história - Guibert usaria tal expediente em Fou de Vincent. Em outro momento, ele coloca em dúvida o caráter referencial das entradas “(esses momentos em que me metamorfoseio, no diário, em personagem de romance)” (p. 411). Em partes de M.A., esse trabalho parece se juntar a provocações de ordem ontológica ao leitor, garantindo a suspensão estatutária de toda sua obra, visto que, concebido para a publicação, o diário serviria como base para a reinterpretação de sua obra e para uma caça às bruxas da verdade e da ficção. Vide os trechos a seguir:

A verdade é a base de 'meu' romanesco, mas 'meu' romanesco prima pela verdade? (p. 449).

Eu amo, no trabalho, o momento em que ele decola imperceptivelmente rumo à ficção após ter ganhado fôlego na pista da veracidade (p. 528).

Para mim, ao fabricar um livro, é em geral quando a narrativa ganha ares de diário que ela é mais ficcional (idem).

Tais afirmações, salpicadas ao longo das 500 páginas, mantêm vivas as dúvidas sobre o estatuto da obra, suspendendo qualquer tentativa de concluir sobre o que é verídico ou imaginário. Como separar os momentos onde ele "se metamorfoseia em personagem de romance" e os momentos onde ele se aferra à transcrição exata do que viveu ou sentiu no diário? M.A. cria uma espécie de mise en abyme da indefinição estatutária e da ambiguidade do pacto de leitura. Assim, se M.A. for lido apenas como mais um romance autoficcional guibertiano, perde-se exatamente o caráter de caixa de segredos que o livro sugere. É na incerteza, não só a respeito da relação duvidosa entre verdade e ficção típica da autoficção, mas sobre o grau de adaptação da matéria bruta do diário, que jaz o apelo estético específico dessa obra.

\section{Do diário editado à poética do inacabado}

Para Braud, o diário "é a mise en intrigue no dia-a-dia de sua existência e pode, evidentemente, explorar todos os recursos habituais da representação do mundo”32. No caso de Guibert, o processo é mais complexo, pois seria preciso dar espaço às “anotações autoficcionais num diário que se oferece como verídico", no qual "cenas reais quase oníricas, transcrições de sonhos ou roteiros romanescos não são distinguidos das descrições reais”. O narrador, por exemplo, explicita sua relação de posse imediata da realidade, pela anotação, pela obsessiva transcrição do vivido $^{33}$. Mas é essa relação de prestação de contas ao diário que lhe permite trazer, para seu espaço de escritura, histórias em potência. E não no sentido de que cada história pudesse ou devesse ser

\footnotetext{
32 BRAUD, M. “Le Texte D'un Roman’: Journal Intime Et Fictionnalisation De Soi.” L'Esprit Créateur, vol. 42, no. 4, 2002, p. 84.

${ }^{33}$ Mesmo no cinema, ele escreve, no escuro, num cheque ou na mão, o que acha do filme (M.A., p. 145). Seria "a doença de ter sempre algo a dizer sobre algo, de escrever como para não perder nada" (idem, p. 157).
} 
romance. A escrita imediata, fragmentária, que Guibert consegue através da notação diarística e à qual submete sua escrita contínua de si depende dessa relação.

Por outro lado, há a pressão para que seu talento se enquadre na forma convencional de um romance. "O editor, que vejo pela primeira vez", diz que "é preciso escrever romances, é só o que vende" (M.A., p. 74). Ao que responde: “Voltarei para vê-lo quando tiver escrito um romance', e sei bem que não o verei pois a ideia do romance, em si, é para mim intolerável” (p. 74). Quando ele começa a escrever um romance, que se chamaria Le désir d'imitation, "logo vem o tédio de uma fabricação" (p. 185). Tal título batiza uma nouvelle de Les aventures singulières. "O romance acabado é talvez uma forma banal de escritura" (p. 186). Ao reler seus cadernos pensando em transformá-los em um livro, diz: "esse livro será feito apenas de síncopes de escritura" (p. 251). Afinal, seu sucesso seria "a decadência de si, da obra" (p. 278).

O diário condensa uma "poética do inacabado" que encontra abrigo não só no elogio da escrita imediata cotidiana como na crítica ao romance realista. O narrador dirá: "Escrever um dia algo sobre as técnicas de inacabamento, quando eu não tiver mais nada eu mesmo para não acabar" (p. 370). "Quando começo uma narrativa, há sempre a ameaça de que ela fique inacabada" (p. 420). O que o toca nos românticos alemães é o caráter inacabado de suas obras, "essa falta de construção, de linearidade, essa forma irritante de adicionar histórias que nada têm a ver" (p. 42). Mais forte seria o exemplo de ratage (falência) quando Hoffmann "confessa sua impotência em escrever seu conto, revelando ao leitor suas receitas de escritor" (idem).

Ora, tanto o caráter inacabado quanto a falta de linearidade, o enxerto de histórias fora da diegese principal e a transparência do método de escrita pela confissão de suas entranhas fazem parte das obras publicadas por Guibert. O autor-narrador-protagonista entrega as chaves desse quarto mágico em que escreve sua obra de estatuto duvidoso: esse espaço onde escreve é dado a ver ao leitor. Quando ele diz que Le récit de la mesquinerie, "em sua forma reescrita a partir do diário" (p. 43), seria um caso de intoxicação por Peter Handke (admiração que o joga numa "mise en écriture fotográfica do quotidiano") e que o livro "em sua forma definitiva não será nada além da transcrição bruta do diário, a história da falência do romance" (idem), o leitor se defronta com uma dupla falência: ao lermos Le récit de la mesquinerie, não encontramos trechos do diário.

Do inacabado intencional chegamos ao caráter de edição a posteriori das entradas originais do diário. "Quando releio esse diário, já tenho uma impressão póstuma” (p. 86), diz o narrador. Seria póstuma no sentido de que a transcrição imediata é natimorta, nasce pronta, não deve ser conjurada pela escrita? Ou seria essa sensação fruto de uma segunda leitura? "Eu posso facilmente ler esse diário como alguém que lê o diário de um morto" (p. 150). Chega um ponto da leitura de M.A. em que o já diário não pode mais ser visto como um simples conjunto de anotações: a unidade na fragmentação é patente e é dada justamente pela relação do autor-narrador com seu trabalho de escrita - e que vai ganhando corpo e densidade com o trabalho de rememoração do que faria parte dos livros por vir (sobretudo Mes parents e À l'ami).

Unidade a não ser confundida com simples formalização ficcional. "O diário é uma espécie de instalação, que joga com a fragmentação e a deriva, numa estética da repetição e da vertigem bem diferente récit clássico”, dirá Lejeune $^{34}$. Instalação que conjura as possibilidades e as registra de forma não menos artística - conjuração feita ao passado e ao futuro e que resgata, no presente da notação, os frutos da experiência como literatura imbuída de

\footnotetext{
${ }^{34}$ Op. cit, p. 5.
} 
verdade. Sentido garantido por essa estética da repetição, da vertigem, a partir do que o narrador sublinha: "Um suspense, como para mim mesmo (como se eu seguisse no cinema a história de um personagem ameaçado): qual será o fim desse livro?” (M.A., p. 328).

Genon diz que o diário guibertiano é um "romance em potência" (2014, p. 90). Mas é também um romance em potência sobre a potência do diário como produtor de literatura. A partir da tensão "entre o vivido e o romanesco, em sua oposição e complementaridade", ganha o escopo de um "recurso criativo capaz de nutrir a totalidade de seu projeto artístico" (p. 91). M.A. pode ser visto como um romance autoficcional sobre a escrita autoficcional em potência.

Mesmo que não esteja claro seu grau de formalização a posteriori, importa pensar como M.A., tratado editorialmente como tal, permite ao leitor-detetive (que imaginamos até aqui como conformado pelo tipo de literatura e de mise en scène da literatura guibertiana) um mergulho nas profundezas do íntimo, não só do autor, mas da fonte de sua literatura ${ }^{35}$. O livro tira sua força do caráter prescritivo de uma escrita em potência, que em parte irá se realizar ao longo da vida de Guibert. É daí que advém uma espécie de prazer voyeurístico único em flagrar o nascimento da ideia, depois em vê-la crescendo e depois ao ser publicada e comentada - ou, ao contrário, abandonada e retomada no luto do narrador como cristalização da escrita apenas como potência. Assim, o leitor alcança uma espécie de domínio do processo como um todo.

Dessa forma, M.A. detém essa poética do inacabado do artista, a potência irrealizável da ideia de romance natimorta. Lado a lado, textos em potência e poética do inacabado dão ao livro uma aura de mergulho às profundezas do autor-narrador-protagonista, de tudo que escreveu, de tudo que poderia ter publicado. Todo o projeto de desnudamento completo de si que a autoficção guibertiana pretendia se encerra neste livro e atinge seu ápice. Há, por exemplo, vários fragmentos do que poderia ter sido o Journal de travail mencionado por Guibert na quarta capa e que vejo como sedo o cerne, o próprio espaço de M.A.. Por exemplo:

\begin{abstract}
Algumas ideias sobre esse projeto de romance (sobre o qual refleti nesses últimos dias na Ilha de Elba, tentado a abandonar a terceira parte dele -- mais, por fim, será bem assim: acabar fazendo essa terceira parte, na impaciência do próximo romance, e um pouco contra ele, como Mes parents já havia lutado contra Les Fantômes): os personagens terão os nomes um pouco mudados (...) eles serão: eu, T., C. Mathieu, Michel, Hans-Georg, Claire, Yvonne). E também: a escritura. (...) A morte de Michel. As relações com Jérôme Lindon. Retomar as coisas desse diário, como uma segunda cronologia paralela - misturá-los, sem costura aparente - e uma cronologia íntima, com seus pedaços de narrativas entremeadas aos episódios mais evidentes, mais fatiados. Da sensação e do acontecimento. Não mais (definitivamente? É a primeira vez que tenho essa ideia dessas!) publicar o diário (M.A., p. 386).
\end{abstract}

"Esse projeto de romance" teria como personagem, além dele próprio e de seus amigos de sempre, ela, "l'écriture". Não haveria costuras aparentes, mas haveria a sensação do "acontecimento". Seguindo esse trecho, Guibert deixaria a ideia de publicar seu diário como tal para, em vez disso, inseri-lo numa "autobiografia da

\footnotetext{
${ }^{35}$ Deixadas de lado qualquer ideia de pureza e qualquer pretensão de verdade absoluta, o diário permite uma fruição de um tipo totalmente distinto do que seriam as nouvelles, a autobiografia (que eu chamo de autoficcional, e que Boulé chama de faux roman) e mesmo de um diário íntimo stricto sensu.
} 
idade adulta" chamada Les Adultes, que teria como tema central "os anos de escrita" (p. 386) e, como modelo, $O$ Homem sem qualidades, de Robert Musil. Tal livro nunca viu a luz do dia. E, se o leitor cruzar tal passagem de M.A. com outros livros publicados de Guibert, crendo em seu estatuto referencial, chegará a conclusões interessantes. Em L'incognito, o narrador guibertiano falava a todo o tempo que estava prestes a terminar "l'histoire de ma vie" (p. 11), na "academia" (a Villa Médicis), já doente de AIDS. Seu próximo livro publicado, porém, será À l'ami, onde ele escreve:

Meu livro condenado, o que comecei no outono de 87 quando ignorava tudo ou fingia ignorar tudo ou quase tudo o que aconteceria comigo, esse livro acabado sobre o qual decretei sua incompletude e demandei a destruição a Jules, sem coragem de fazê-lo eu mesmo e pedindo que fizesse o que eu neguei a Muzil, esse grande e fastidioso livro, plano como uma cronologia, que contava minha vida de dezoito a trinta anos, se chamava "Adultes!" (p. 236).

Se no primeiro excerto, o do diário, temos uma espécie de sinopse do que seria um livro, um resumo com uma de receita de escritura (quais materiais autobiográficos, a escritura sendo o principal deles, qual diegese, que cronologias, que sensação transmitir ao leitor), no segundo excerto, de $\grave{A}$ l'ami, encontramos o resumo da falência do livro, sua ratage, termo tão caro a Guibert. Inferimos, do segundo excerto, que o livro en chantier foi decretado morto por causa da AIDS. Michel Foucault virou Muzil, em alusão ao Musil cujo livro inspiraria sua autobiografia da idade adulta. $O$ trecho segue, dizendo que o livro nunca veria seu fim por sua incapacidade de enfrentar sua "verdadeira primeira frase" (p. 237): "Era preciso que a desgraça caísse sobre nós'. Era preciso, que horror, para que meu livro visse a luz do dia" (idem).

Para Lejeune ${ }^{36}$, o diário (de um escritor, que se lê como literatura) é um processo que conhece três fases, encaixadas (emboitées) uma na outra: primeiro, "uma parte secreta, composta pelo vai-e-vem de nossa vida e da escritura, que deixam sobre o papel os traços nos quais o explícito serve de suporte ao implícito abundante e de motor da ação cotidiana"; segundo, a releitura do autor, a partir da qual "essa massa em fusão começa a se solidificar", que pode ser uma "releitura de proximidade", ligeira, sem pretensões, e outra, "a releitura longínqua", que "autobiografiza" o diário e prepara a terceira fase, a leitura por um outro.

Em M.A., é fácil visualizar o processo diarístico como pensa Lejeune. No diário de Guibert, é comum o autocomentário do próprio diário como fruto explícito da releitura dos fragmentos anteriores, tido como exercício fundamental para a continuidade da escrita (e da vida). Por exemplo, quando o narrador escreve: "A morte de B." (M.A., p. 104), frase solta, espécie de entrada que pede um retrabalho posterior, no sentido de fazer germinar, na memória, a necessidade de se debruçar sobre o assunto. Na sequência (dias depois), o narrador retoma a frase: "A brevidade da nota sobre a morte de B. pode parecer uma baixa, uma indiferença chocante ou um efeito estilístico, e é tudo isso ao mesmo tempo” (idem, p. 106-107).

Vejamos o exemplo do enxerto em potência das letras de T. ao diário que comenta o autor-narrador - o que faria sentido, se pensarmos que, a essa altura, o diário já parece funcionar como essa "espinha dorsal" da qual saem os escritos publicáveis do autor:

\footnotetext{
${ }^{36}$ Op. cit., p. 11.
} 
Tentei retomar as cartas de T. para destacar e copiar seus fragmentos com a ideia de incorporá-los esse diário, e com elas fechar a primeira parte. Mas rapidamente (antes mesmo de começar, aliás, assim que havia lido todas as cartas), esse trabalho me entedia, me parece absurdo: pois essas cartas são cartas mesmo, e têm outra textura que o diário, mais livre, mais dispersa, mais fútil, mais real também (M.A., p. 128, grifos meus).

Na página seguinte, ele escreve "Nas cartas que escrevi a T." (p. 129), ao que seguem dez fragmentos, entre aspas, com o que seriam os excertos das tais cartas que ele havia decidido, como vimos, não mais incorporar ao diário. Mais do que fazer o contrário do que se propôs antes, o narrador se prova errado, confirmando a riqueza, para a escritura, do diálogo entre os fragmentos do diário - o que referenda a noção de Braud de que a transcrição parece se trair, mas é, na verdade, fiel ao momento, visto que a natureza imediata da notação parece demandar um outro trabalho, da memória, na releitura: "a verdade da descrição íntima é relativa ao sujeito e ao instante de enunciação (...) A transcrição pode ser denunciada como falsa no instante que segue; ela foi, porém, autêntica no momento da enunciação", diz Braud ${ }^{37}$.

Braud separa a empreitada diarística em três possibilidades: o diário estritamente tomado da experiência cotidiana, transcrição direta da vida no dia-a-dia; o diário que nasce autoficcional - do qual o autor aproveitaria a forma, e que Braud define como autoficção; e aquele em que o caráter "romanesco" da mise en intrigue é colocado, sem perda da relação referencial, ao menos para o autor. O diário de Guibert, penso, seria os três ao mesmo tempo e é justamente o fato de o autor denunciar todas essas possibilidades, num eterno vai-e-vem de percepções, o que faz de M.A. um livro único.

\section{O autor e sen canteiro de escrita, de bandeja para o leitor}

Ao se fazer publicar, M.A. entrega ao leitor todas as receitas do escritor, tanto as que ele explica quanto as que se inscrevem nas entrelinhas do livro. São receitas para identificar o estatuto de sua literatura autoficcional; para conhecer de perto, de dentro, seus processos de escritura (inclusive o leurre, o jogo entre verdade e ficção que engana um leitor que quer, até certo ponto, ser enganado, desde que sinta o suprassumo de verdade); seu espaço de escritura (e todo seu arcabouço de experimentações com linguagem e estilo, do qual o diário é a melhor materialização possível); a origem de suas histórias (para acreditar se quiser) e o percurso de sua evolução, da evolução dessas histórias em contos e romances (publicados ou falhos, ratés); e, sobretudo, para poder apreender, num único livro, da forma mais voyeurística impossível, o que ele espalhara ao longo de dezenas de obras - a ver, como diria Lejeune a respeito de Michel Leiris, essa espécie de "movimento perpétuo da escritura de si”

O diário também serve para contar a agonia do escritor impublicável, que sonha com a resposta do leitor imaginário: ao mencionar seus romances rejeitados, que "bloqueiam a escritura" (M.A., p. 161), ele diz que a publicação de um deles "provocaria o desentupimento de uma pia", e a escritura, assim, poderia voltar a fluir. Mas faltar-lhe-ia o encontro com esse "único leitor" (p. 161), cuja leitura é uma "oração" (p. 166), leitor que toma o livro como uma "hóstia", que receberia a escritura como inseminação, vinte anos depois. Afinal, o livro, "é a imaginação dos outros que o faz, que o refabrica" (p. 196). O livro é "uma demanda de amor" (p. 199. É assim

\footnotetext{
${ }^{37}$ Op. cit., p. 77.

${ }^{38}$ Op. cit, p. 5.
} 
que, pela primeira vez, o narrador se dirige ao leitor: "E tu, leitor ou leitora dessas linhas, se tu não tens mais nenhuma esperança, tu podes sempre encontrá-la, mesmo que te sintas sozinho(a) saiba que, da minha tumba, eu quero te reconfortar como acabam de fazer por mim" (p. 375).

Deixando de lado a tentação crítica de supor o enxerto das frases anteriores ao diário original, como faz Genon, vale pensar ao menos o efeito que tal frase tem na leitura: qual é o fim da história, além da morte do autor? Que tipo de impacto tem dirigir-se diretamente ao leitor sobre o estatuto genérico do diário? Aumentar seu grau de intimidade com o leitor, seu grau patético, ou reduzir a confiança na existência autônoma do diário como diário de um escritor - seria, afinal, essa a intenção de Guibert aqui, sua "guibertinage"? Acho que podemos responder de forma positiva a todas as questões. É ao erodir as certezas do leitor, num vai-e-vem eterno, que o autor-narrador-protagonista se faz mais vivo e presente.

Com M.A., Guibert encerra seu projeto autoficcional de forma triunfal. Ao publicar um diário póstumo (o volume foi publicado apenas dez anos após a morte do autor, tempo exigido em testamento), Guibert oferece ao leitor não só as chaves para compreender a gênese e o sentido de seus livros como explicita o caráter inerentemente indecidível do estatuto de toda a sua obra. Todas as estratégias de persuasão, sua relação com o espaço de escritura (agora sacralizado, finalmente, como obra final) do diário, sua relação dialética com a escritura, entre a verdade originária da experiência e a ficcionalidade intrínseca à narrativa -- tudo é entregue ao leitor de bandeja, como um manual de instruções em forma de literatura.

Corolário póstumo do jogo literário guibertiano, M.A. delineia ainda a poética do inacabado que ilumina a escritura guibertiana (sobretudo quando vista sob o signo teleológico da morte). Romance autoficcional sobre a escrita autoficcional em potência, o livro é um eterno convite a navegar a obra inteira de Guibert, instaurando a possibilidade de uma trajetória cíclica e interminável por sua literatura. Uma "mise en écho", como disse Genon $^{39}$, que insere qualquer livro no manancial dos outros, processo de metonímia natural e de retrocontaminação que faz da obra de Guibert uma rede de partes indissociáveis - e M.A. seria o golpe de mestre final.

Creio que o que sobressai de tudo o que Guibert fez é antes a dimensão de uma única escrita de si, de um organismo vivo, de uma "architexture", para endossar o neologismo de Genon (idem, pos. 1728). Guibert não era Proust, mas criou sua catedral autoficcional. E assim, por tabela, sobressai igualmente o papel do leitor em retrabalhar constantemente a gramática autobiografemática do autor e organizar a narrativa sobre Guibert, sobre sua escrita conforme seu próprio mundo (o do leitor). Obra aberta, intratextualmente inseparável, M.A. convoca o leitor a decidir. Tudo sobre Guibert, sua literatura, a própria literatura em potência.

\section{Referências bibliográficas}

Blanckeman, Bruno. Les récits indécidables : Jean Echenoz, Hervé Guibert, Pascal Quignard. Villeneuve d'Ascq: Presses universitaires du Septentrion, 2008

Boulé, Jean-Pierre. Hervé Guibert : L'entreprise du moi. Paris: L'Harmattan, 2001.

BRAUD, Michel. La Forme des jours: pour une poétique du journal personnel. Paris: Seuil, 2006.

\footnotetext{
${ }^{39}$ GENON, Arnaud. Hervé Guibert : vers une esthétique postmoderne. Paris : L'Harmattan, 2007. Versão Kindle. Roman, journal, autofiction: Hervé Guibert en ses genres. Paris: Mon Petit Editeur, 2014
} 
“'Le Texte D'un Roman': Journal Intime Et Fictionnalisation De Soi.” L'Esprit Créateur, vol. 42, n. 4, 2002.

CATELLi, N. En la era de la intimidad: seguido de El espacio autobiográfico. Rosario: Beatriz Viterbo, 2007.

DIDIER, Béatrice. Le journal intime. Paris: PUF, 1976.

GASPARINI, Philippe. Est-il jeu ? Paris: Seuil, 2004.

GUIBERT, Hervé. L'image fantôme. Paris: Éditions de minuit, 1981.

Les aventures singulières. Paris: Éditions de minuit, 1982.

Mes parents. Paris: Gallimard, 1986.

Les gangsters. Paris: Éditions de minuit, 1988.

Voyage avec deux enfants. Paris: Éditions de minuit, 1988. Fou de Vincent. Paris: Éditions de minuit, 1989 .

À l'ami qui ne m'a pas sauvé la vie. Paris: Gallimard, 1990.

Le mausolée des amants. Paris: Gallimard, 2001.

LejEUNE, Philippe. “Le journal comme 'antifiction”. Poétique, n. 149, 2007.

. Le pacte autobiographique. Paris: Éditions du Seuil, 1975.

PRADO BIEZMA, J. et alii. Autobiografia y modernidad literaria. Cuenca: Ediciones de la Universidad de Castilla-La Mancha, 1994.

VIEIRA, Willian. 'Em literatura pode-se dizer tudo'. Poética do eu, ontologia do não-limite e política da autoficção em Hervé Guibert, Christine Angot e Ricardo Lísias. 2019. Tese (Doutorado em Letras) Universidade de São Paulo. Orientadora: Claudia Amigo Pino.

VIGNA, Gaetano Antonio. "El peso de mis autobiografemas. Construcción de la identidad en el mundo de juan josé millás". Tonos Digital, 2018

Recebido em: 17 de setembro de 2020

Aceito em: 26 de outubro de 2020 